\title{
PEMBENTUKAN KATA PADA ISTILAH KHAS DI INSTAGRAM DENGAN UNSUR BAHASA INGGRIS
}

\author{
Saidatun Nafisah ${ }^{1}$, Iwan Budiarso ${ }^{2}$ \\ ${ }^{1}$ Fakultas Bahasa dan Seni, Universitas Indraprasta PGRI \\ ${ }^{2}$ Fakultas Teknik dan Ilmu Komputer, Universitas Indraprasta PGRI \\ ${ }^{1}$ saida.unindra@gmail.com, ${ }^{2}$ budiarso.iwan@gmail.com
}

\begin{abstract}
Abstrak
Tujuan dari penelitian ini adalah untuk mengetahui struktur pembentuk kata khas yang mengandung unsur bahasa Inggris pada Instagram serta implikasinya terhadap situasi kebahasaan di Indonesia. Data penelitian berupa data tulisan dari pengguna Instagram. Sampel data diambil dengan teknik purposive sampling, yaitu dengan melihat interaksi ditiap akun yang dijadikan sebagai sumber. Metode yang digunakan adalah deskriptif kualitatif. Pendekatan yang digunakan adalah morfologi dan sosiolinguistik. Hasil menunjukkan bahwa terdapat banyak istilah khas di Instagram Indonesia yang menggunakan unsur bahasa Inggris. Struktur istilah tersebut ditemukan dalam berbagai bentuk kombinasi bahasa, antara lain bahasa Inggris + bahasa Inggris, bahasa Inggris + bahasa Indonesia, dan bahasa Indonesia + bahasa Inggris. Istilah-istilah tersebut terbentuk melalui berbagai macam proses morfologis, antara lain proses derivating, compounding, abbreviating, blending, acronym, dan borrowing. Sebagian istilah khas mengikuti kaidah pembentukan kata dengan sistem bahasa Inggris dan sebagian yang lainnya mengikuti sistem bahasa Indonesia. Sebaliknya, terdapat kosakata yang mengikuti sistem bahasa Indonesia. Terbentuknya kosakata baru melalui proses yang bermacam-macam merupakan proses kreatif manusia yang dapat memberikan dampak positif terhadap perbendaharaan kosakata baru terhadap suatu bahasa. Namun, pembentukan kosakata baru yang tidak mengikuti kaidah bahasa yang benar dapat mengacaukan sistem bahasa yang sudah ada.
\end{abstract}

Kata Kunci: Pembentukan Kata, Istilah Khas, Bahasa Inggris, Instagram

\begin{abstract}
The purpose of this study is to determine the structure of the typical word-forming elements containing English on Instagram and their implications for the linguistic situation in Indonesia. The research data are in the form of writing data taken from Instagram users. Data samples were taken using purposive sampling technique, which is by looking at interactions in each account that are used as a source. The method used is descriptive qualitative. The approach used are morphology and sociolinguistics. The results show that there are many distinctive terms on Instagram Indonesia that use elements of English. The word structures of the typical terms found in Instagram are made of various language combinations, such as English + English, English + Indonesian, and Indonesian + English. These terms are formed through a variety of morphological processes, including the process of derivating, compounding, abbreviating, blending, acronyming, and borrowing. Some typical terms follow the rules of word formation with the English system and some others follow the Indonesian language system. Instead, there are some words that follows the Indonesian language system. The formation of new vocabulary through various processes is a creative human process that gives a positive impact on building new vocabularies on a language. Meanwhile, the formation of new vocabulary that does not follow the rules of the correct language can disrupt the existing language system.
\end{abstract}

Keywords: Word Formation, Typical Terms, English Language, Instagram 


\section{PENDAHULUAN}

Pada saat ini, perkembangan teknologi khususnya di bidang komunikasi digital sangatlah pesat. Kehadiran ponsel pintar atau yang lebih akrab di telinga kita dengan sebutan smart phone lengkap dengan kecanggihan fitur dan aplikasinya membuat perubahan besar dalam era ini. Ditambah lagi dengan kehadiran media sosial yang memberikan nuansa baru terhadap cara berkomunikasi manusia di bidang hubungan sosial, pekerjaan, pendidikan, perniagaan, dan lain sebagainya.

Salah satu perubahan besar terjadi dalam ranah niaga. Kemajuan teknologi dan munculnya media sosial dapat mengubah tata cara dan perilaku berniaga. Segala urusan yang tadinya dilakukan secara konvensional kini dapat berubah menjadi serba online; mulai dari penjual yang memajang dagangan hanya melalui foto, negosiasi antara pedagang dan pembeli yang melalui chat atau text message, hingga cara pembayaran yang dilakukan dengan cara mentransfer uang melalui ATM, internet banking, ataupun mobile banking. Praktek jual beli online ini dianggap lebih cepat, mudah, praktis, dan tentunya moderen. Antara pedagang dan pembeli tidak perlu saling bertatap muka langsung. Oleh karenanya keberadaan toko online ini semakin hari semakin marak. Karena cara membangun sebuah toko online yang sangat mudah, setiap orang pun dapat membuat toko online sendiri. Contoh toko online yang marak sekarang ini adalah yang dibuat di media sosial seperti Instagram.

Perubahan cara berniaga ini tentu berpengaruh terhadap cara berkomunikasi dan bahasa yang digunakan. Tidak heran apabila istilah-istilah baru pada ranah bisnis online banyak bermunculan. Uniknya, setiap media sosial memiliki istilah khasnya masingmasing. Dalam penelitian ini, peneliti akan mencoba mengumpulkan istilah-istilah khas yang mengandung unsur bahasa Inggris di media sosial Instagram dan menelaahnya dari sudut pandang linguistik. Pada kesempatan ini, penulis akan mengkaji istilah-istilah khas di Instagram yang berkaitan dengan bisnis online dengan alasan bahwa istilah-istilah khas banyak ditemukan pada ranah ini. Kajian ini juga terbatas pada istilah-istilah khas yang mengandung unsur bahasa Inggris dengan alasan bahwa bahasa Inggris banyak digunakan untuk membentuk istilah-istilah di media sosial.

Berdasarkan uraian yang sudah disampaikan diatas, pertanyaan penelitian ini kemudian dirumuskan menjadi:

1. Istilah apa saja yang ditemukan dalam bisnis online di instagram yang mengandung unsur bahasa Inggris?

2. Bagaimana struktur pembentuk istilah-istilah tersebut?

3. Apa implikasi dari munculnya istilah-istilah tersebut terhadap situasi kebahasaan di Indonesia?

Istilah media sosial (social media) saat ini menjadi sangat populer di kalangan masyarakat seluruh dunia. Media sosial adalah saluran atau sarana pergaulan sosial secara online di dunia maya (internet). Para pengguna (user) media sosial berkomunikasi, berinteraksi, saling kirim pesan, dan saling berbagi (sharing), dan membangun jaringan (networking) (Romeltea, 2014).

Gamble, Teri, dan Michael dalam Communication Works (dalam Romeltea, 2014) menyebutkan, media sosial mempunyai ciri - ciri sebagai berikut:

1. Pesan yang disampaikan tidak hanya untuk satu orang saja namun bisa keberbagai banyak orang contohnya pesan melalui SMS ataupun internet

2. Pesan yang disampaikan bebas, tanpa harus melalui suatu gatekeeper

3. Pesan yang disampaikan cenderung lebih cepat dibanding media lainnya

4. Penerima pesan yang menentukan waktu interaksi 
Sebagai salah satu media komunikasi, media sosial tidak hanya dimanfaatkan untuk berbagi informasi dan inspirasi, tapi juga ekspresi diri (selfexpression), "pencitraan diri" (personal branding), dan ajang "curhat" bahkan keluh-kesah dan sumpah-serapah. Selain itu, sosial media juga sering dijadikan sebagai sarana berniaga secara online (Romeltea, 2014). Sosial media yang populer di Indonesia saat ini antara lain: Instagram, Line, Facebook, Youtube, Google Plus, dan sebagainya.

Ketika berbicara tentang pembentukan suatu kata, maka pendekatan yang digunakan adalah morfologi. Secara etimologi kata morfologi berasal dari kata morf yang berarti 'bentuk' dan kata logi yang berarti 'ilmu'. Jadi, secara harfiah kata morfologi berarti 'ilmu mengenai bentuk'. Di dalam kajian linguistik, morfologi berarti ilmu mengenai bentuk-bentuk dan pembentukan kata (Chaer, 2008: 3).

Untuk mengetahui unsur pembentuk kata, maka perlu memahami konsep-konsep yang dibahas dalam morfologi. Delahunty dan Garvey (2010:121) menjelaskan bahwa ada beberapa konsep dasar yang dibahas dalam morfologi bahasa Inggris, yaitu: words and morphemes root, derivational, inflectional morphemes, morphemes, allomorphs, morphs, Words, English inflectional morphology, English derivational morphology, compounding, other sources of words, registers and words, internal structure of complex words, and classifying words by their morphology.

Dalam sistem morfologi bahasa Inggris, pembentukan kosakata secara umum melalui dua kategori proses morfologi, yaitu inflection dan derivation. Inflection merupakan proses pembentukan kata yang tidak merubah kelas kata. Derivation is the process of creating separate but morphologically related words. Typically, but not always, it involves one or more changes in form (Delahunty dan Garvey, 2010: 129). Derivation adalah proses morfologi pembentukan kata yang dapat merubah bentuk kata (kelas kata). Delahunty dan Garvey (2010: 136) menambahkan bahwa selain melalui proses derivating ada proses morfologi lain yang dapat membentuk kosakata baru seperti compounding, coining, abbreviating, blending, dan borrowing.

Interferensi merupakan perubahan sistem suatu bahasa sehubungan dengan adanya persentuhan bahasa tersebut dengan unsur-unsur bahasa lain yang dilakukan oleh penutur bilingual (Chaer dan Agustina, 2004: 120). Interferensi ini dianggap sebagai suatu kesalahan karena penggunaan serpihan bahasa lain dapat merusak sistem suatu bahasa. Hal ini juga diungkapkan oleh Kridalaksana (2001: 84) bahwa interferensi adalah kesalahan berbahasa berupa unsur bahasa sendiri yang dibawa kedalam bahasa lain yang sedang dipelajari.

Interferensi dapat terjadi pada tingkat fonologi, morfologi, dan sintaksis. Masuknya serpihan bahasa lain ke dalam suatu bahasa juga dikaitkan dengan peristiwa alih kode. Namun, dua peristiwa kebahasaan ini sangatlah berbeda. Untuk membedakannya dengan kasus alih kode, Chaer dan Agustina (2004: 124) menjelaskan bahwa campur kode mengacu pada digunakannya serpihan-serpihan bahasa lain dalam menggunakan suatu bahasa tertentu; sedangkan interferensi mengacu pada adanya penyimpangan dalam menggunakan suatu bahasa dengan memasukkan sistem bahasa lain.

Meskipun dianggap mengacaukan suatu sistem bahasa, pada sisi lain interferensi dianggap dapat membawa manfaat dalam memperkaya kosakata suatu bahasa. Dengan interferensi, kosakata bahasa resipien menjadi diperkaya oleh bahasa donor, yang pada mulanya dianggap sebagai unsur pinjaman, tetapi tidak lagi karena kosakata tersebut beringtegrasi menjadi bagian dari bahasa resipien (Chaer dan Agustina, 2004: 128). Integrasi sendiri adalah unsur-unsur bahasa lain yang diunakan dalam bahasa tertentu dan 
dianggap sudah menjadi warga bahasa tersebut (Mackey dalam Chaer dan Agustina, 2004: 128). Proses integrasi ini memerlukan waktu dan tahap yang relatif panjang hingga akhirnya sebuah kata 'pinjaman' dapat dijadikan bagian dari kosa kata suatu bahasa.

Beberapa penelitian mengenai interferensi pernah dilakukan oleh (Mustikawati, 2006). Tujuan penelitian yang dilakukannya adalah (1) untuk mengidentifikasi bentukbentuk interferensi bahasa Indonesia dalam pemakaian bahasa Inggris wacana tulis siswa SMA Muhammadiyah I Ponorogo, (2) untuk mendeskripsikan faktor-faktor yang melatarbelakangi interferensi, (3) untuk mendeskripsikan pengaruh interferensi terhadap kemampuan siswa dalam menulis wacana, (4) serta mendeskripsikan upaya-upaya untuk menanggulangi interferensi bahasa Indonesia ke dalam pemakaian bahasa Inggris wacana tulis siswa. Analisis yang digunakan adalah analisis isi (content analysis) untuk menganalisis setiap tuturan dalam wacana. Teknik analisis data menggunakan metode padan referensial dan analisis komponen tutur Dell Hymes. Hasil menunjukkan bahwa ditemukan bentuk-bentuk interferensi bahasa Indonesia ke dalam pemakaian bahasa Inggris wacana tulis yaitu penggunaan frasa nomina terdiri dari nomina diikuti nomina, nomina diikuti adjektiva, penggunaan kata ganti milik, penggunaan adjektiva, penggunaan numeralia, penggunaan kata keterangan waktu, penggunaan kata penunjuk tempat, penggunaan adverbia, penggunaan konjungsi yang menyatakan hubungan makna cara, penggunaan kata keterangan yang menunjukkan kualitas, dan penggunaan kalimat. Faktor-faktor yang melatarbelakangi interferensi bahasa Indonesia dalam pemakaian bahasa Inggris wacana tulis siswa dapat dibagi menjadi faktor kebahasaan dan nonkebahasaan.

Penelitian interferensi yang lain dilakukan oleh Saragih (2013). Tujuan penelitian ini adalah untuk mengetahui (1) bagaimana kesalahan interferensi B1 dalam penggunaan adposisi bahasa Jepang, (2) bagaimana interferensi hubungan gramatikal dalam penggunaan adposisi bahasa Jepang yang muncul pada bahasa tulis, dan (3) bagaimana tingkat kesulitan adposisi bahasa Jepang berdasarkan interferensi yang muncul pada bahasa tulis mahasiswa angkatan 2010 sastra Jepang Universitas Brawijaya, Malang. Hasil menunjukkan bahwa terdapat interferensi bahasa Indonesia pada penggunaan adposisi bahasa Jepang dalam kalimat yang dibuat siswa. Interferensi hubungan gramatikal yang terjadi pada penggunaan adposisi bahasa Jepang dalam bahasa tulis yang dibuat siswa adalah transfer hubungan gramatikal B1 melanggar pola hubungan gramatikal B2, tetapi maknanya masih bisa dimengerti secara tersirat.

Dua penelitian di atas mengambil sumber data dari siswa atau mahasiswa. Data yang diambil merupakan data bahasa tertulis, yaitu tulisan siswa atau mahasiswa. Pada penelitian ini, penulis akan mencoba menelaah interferensi pada data tulis yang bersumber dari media sosial instagram dengan cara mengambil sampel dari beberapa akun instagram dengan follower yang berjumlah lebih dari sepuluh ribu. Karena yang menjadi fokus peneliti adalah bentuk istilah-istilah khas Instagram yang mengandung bahasa Inggris, penulis akan menelaah interferensi pada tingkat leksikal. Pendekatan morfologi digunakan untuk mengetahui proses pembentukan istilah-istilah tersebut.

\section{METODE PENELITIAN}

Metode penelitian yang digunakan peneliti adalah metode deskriptif kualitatif. Menurut Sudaryanto (1993: 62), metode kualitatif mengacu pada penelitian yang berkaitan dengan data penelitian yang tidak berupa angka, tetapi berupa kata atau frasa. Analisis deskriptif merupakan proses menggambarkan fenomena yang terjadi saat ini dengan menggunakan prosedur ilmiah untuk menjawab masalah aktual (Sudaryanto, 1993: 62). Analisis 
deskriptif dipilih untuk memperoleh gambaran yang sistematis mengenai data-data penelitian yang kemudian dikelompokkan menurut pola tertentu.

Data penelitian ini adalah kosakata atau istilah-istilah yang mengandung unsur bahasa Inggris di media sosial instagram, khususnya yang dipakai pada interaksi jual beli online. Sumber data penelitian ini adalah orang Indonesia pengguna instagram yang menjadikan akunnya sebagai toko online. Karena data diambil dari interaksi di media sosial instagram, maka data yang diperoleh adalah data tertulis.

Agar peneliti yakin bahwa data yang diperoleh absah dan mewakili, maka peneliti akan melakukan triangulasi data dengan cara melibatkan data lebih dari satu sumber (Mahsun, 2007: 237). Sejauh ini, peneliti melihat bahwa toko online yang banyak dijumpai di instagram adalah toko yang menjual produk fesyen. Dengan alasan ini, peneliti mengambil sampel data dari sumber data yang berbeda, yaitu toko online di instagram dengan kategori fesyen wanita, fesyen pria, dan fesyen anak.

Metode penyediaan data penelitian sosiolinguistik dapat berupa metode simak, survei, dan cakap (Mahsun, 2007). Yang digunakan dalam penelitian ini adalah metode simak dengan teknik simak bebas libat cakap (SLBC). Mahsun (Mahsun, 2007) menjelaskan bahwa dengan teknik ini, peneliti melakukan penyimakan penggunaan bahasa dalam suatu peristiwa tutur dengan tanpa keterlibatannya dalam peristiwa tutur tersebut.

Peneliti menyimak (membaca, red.) interaksi antara penjual dan konsumen dan mendokumentasikan sampel kosakata atau istilah-istilah di instagram yang mengandung unsur bahasa Inggris. Sumber data yang dipilih adalah toko online di instagram yang memiliki lebih follower atau pengikut lebih dari seratus ribu akun. Peneliti menetapkan standar tersebut dengan harapan ada banyak data yang bisa dijaring. Ada banyak istilah khas di instagram. Oleh karenanya, dalam menjaring data teknik yang digunakan peneliti adalah purposive sampling. Peneliti hanya akan mengambil istilah-istilah khas di instagram yang mengandung unsur bahasa Inggris. Supaya dapat mengakses akun-akun tersebut, maka peneliti harus terlebih dahulu menjadi pengguna instagram dan menjadi follower dari akun-akun yang dijadikan sebagai sumber data.

Setelah mendapatkan data, langkah selanjutnya adalah menganalisis data. Dalam menganalisis proses pembentukan sebuah kata, penulis melakukan beberapa tahap analisis. Pertama, data yang sudah terkumpul kemudian diidentifikasi dan dikelompokkan berdasarkan bahasa yang digunakan, apakah murni bahasa Inggris saja ataukah gabungan antara bahasa Inggris dan bahasa Indonesia. Setelah itu, peneliti menganalisis proses pembentukan kata (word formation). Pada tahap ini, peneliti menggunakan pendekatan morfologi. Langkah selanjutnya adalah mendeskripsikan proses morfologis yang terjadi dilanjutkan dengan menemukan pola morfologis pembentukan istilah-istilah khas di instagram. Jika ditemukan adanya pembentukan kata yang terdiri dari gabungan dari bahasa Inggris dan bahasa Indonesia, peneliti akan membuat analisis sistem bahasa yang digunakan pada kata tersebut.

Peneliti juga mengkaji kemungkinan adanya interferensi dan integrasi bahasa pada penggunaan kosakata atau istilah yang mengandung unsur bahasa Inggris di toko online instagram. Peneliti menggunakan bantuan kamus kata serapan bahasa asing untuk mendeteksi kata-kata tersebut masuk ke dalam kategori interferensi atau integrasi. Dengan demikian penelitian ini akan mencakup analisis pembentukan kata dan juga penggunaannya. Selanjutnya, peneliti mencari implikasi dari hasil penelitian ini terhadap situasi kebahasaan di Indonesia. 
Hasil analisis dalam penelitian ini akan disajikan dengan metode informal dan formal. Metode penyajian formal dan informal merupakan teknik perpaduan yang menggunakan kata-kata dan tanda-tanda atau lambang (Sudaryanto, 1993: 145). Penulis menyajikan hasil analisis dalam bentuk deskripsi. Data penelitian dijabarkan berdasarkan landasan teori yang digunakan dalam bentuk uraian. Pembentukan kata dari istilah khas di Instagram dipolakan berdasarkan kategorinya masing-masing. Penulis akan menggunakan tanda atau lambang untuk menunjukkan pola yang ditemukan.

\section{HASIL DAN PEMBAHASAN}

Pada bagian ini akan dipaparkan hasil penelitian yang terdiri dari hasil temuan dan pembahasan. Sumber data diambil dari 15 akun atau user instagram yang terdiri dari 5 akun kategori toko online fesyen wanita, 5 akun kategori toko online fesyen pria, dan 5 akun kategori toko online fesyen anak. Setelah menjaring data dari toko online di media sosial Instagram yang jumlah pengikutnya sudah berjumlah lebih dari seribu, maka peneliti menemukan berbagai macam istilah khas. Berikut adalah tabel pengguna Instagram yang dijadikan sumber data.

Tabel 1. Daftar Sumber Data Akun Instagram

\begin{tabular}{lllc}
\hline No & \multicolumn{1}{c}{ User IG } & \multicolumn{1}{c}{ Kategori } & $\begin{array}{c}\text { Jumlah } \\
\text { Followers* }\end{array}$ \\
\hline 1 & @ vanillahijab & Fesyen Wanita & $553 \mathrm{k}^{*}$ \\
2 & @ hijabprincess & Fesyen Wanita & $305 \mathrm{k}$ \\
3 & @atelier.angelina & Fesyen Wanita & $283 \mathrm{k}$ \\
4 & $@$ heaven_lights & Fesyen Wanita & $219 \mathrm{k}$ \\
5 & @muchabadres & Fesyen Wanita & $129 \mathrm{k}$ \\
6 & @asrstore & Fesyen Pria & $19 \mathrm{k}$ \\
7 & $@$ mensoriginalbranded & Fesyen Pria & $83 \mathrm{k}$ \\
8 & @menstuff_shop & Fesyen Pria & $160 \mathrm{k}$ \\
9 & @mensrepublicid & Fesyen Pria & $53.1 \mathrm{k}$ \\
10 & $@$ maleid & Fesyen Pria & $23.4 \mathrm{k}$ \\
11 & @ fashionkidsbranded & Fesyen Anak & $150 \mathrm{k}$ \\
12 & @gayasikecil & Fesyen Anak & $14.3 \mathrm{k}$ \\
13 & @aurel_outlet & Fesyen Anak & $23 \mathrm{k}$ \\
14 & @kemeja_brandedkids & Fesyen Anak & $13 \mathrm{k}$ \\
15 & @artbast_mykids & Fesyen Anak & $26 \mathrm{k}$ \\
\hline
\end{tabular}

*Jumlah followers per 30 Nop 2016

** K adalah singkatan dari 'kilo' yang artinya 'ribu'

Berikut ini adalah pembahasan mengenai istilah khas yang berhasil ditemukan. Pembahasan mengenai pembentukan kata di bawah ini dilengkapi dengan penambahan keterangan makna untuk masing-masing istilah khas Instagram yang ditemukan. Makna yang dijelaskan dalam penelitian ini ditulis berdasarkan pengetahuan penulis. Hal ini dilakukan karena istilah-istilah yang dibahas di penelitian ini sifatnya adalah terbatas. Terbatas yang dimaksud adalah istitah-istilah tersebut lazim digunakan di media sosial Instagram namun masih terdengar asing bagi orang awam yang belum pernah berinteraksi di media sosial tersebut. Oleh karena sifatnya yang terbatas, maka makna istilah-istilah tersebut tidak dapat dicari di kamus. Untuk menghindari subjektifitas, maka penulis 
melakukan triangulasi dengan cara mencari referensi berupa artikel-artikel yang menjelaskan makna atau pengertian mengenai istilah-istilah khas Instagram seperti yang ditulis oleh (Maghribi, 2016) dan yang terdapat di laman http://tekoneko.net/istilahdalam-instagram/ (Anonym, 2016).

Pada bagian ini, bahasan hasil penelitian dibagi ke dalam dua poin pokok, yaitu pembahasan mengenai pembentukan kosakata dengan unsur bahasa Inggris dan pembahasan tentang istilah khas sebagai register.

\section{Istilah Khas di Instagram dengan Unsur Bahasa Inggris}

Banyak istilah yang mengandung unsur bahasa Inggris yang dapat ditemukan di media sosial Instagram. Sampel yang penulis ambil sebagai data adalah kata yang cukup khas di pakai di media sosial tersbut. Berikut ini adalah data kosakata atau istilah khas tersebut.

Tabel 2 Data Kosakata Khas Instagram yang Mengandung Unsur Bahasa Inggris

\begin{tabular}{|c|c|l|}
\hline A & $:$ & \multicolumn{1}{|c|}{ Activity Feed } \\
\hline B & $:$ & Best Seller, Bio, Busui Friendly \\
\hline C & $:$ & Caption, Chat Order, Comment \\
\hline D & $:$ & Del, Delsoon, Double Upload, Done, Dropship, DM \\
\hline E & $:$ & Endorse \\
\hline F & $:$ & Fast Response, Follback, Follower, Format Order, Free Ongkir \\
\hline G & $:$ & Geotag, Ghost Follower, Giveaway \\
\hline H & $:$ & Hashtag, Hit and Run \\
\hline I & $:$ & IDR, IG, IGers \\
\hline K & $:$ & K, K/D \\
\hline L & $:$ & Latepost, LFL \\
\hline N & $:$ & Newsfeed, No Cancel, No Gembok \\
\hline O & $:$ & Olshop, Online, OOTD, Open Order \\
\hline P & $:$ & Paid Keroyok, Paid Promote, Pict, PO,, \\
\hline R & $:$ & Real Pict, Repost, Reseller \\
\hline S & $:$ & SFS, Spam Like, Supplier \\
\hline U & $:$ & Upload \\
\hline W & $:$ & Wudhu Friendly \\
\hline
\end{tabular}

Dalam sistem morfologi bahasa Inggris, pembentukan kosakata secara garis besar dibagi menjadi dua, yaitu inflectional words dan derivational words. Data yang diperoleh menunjukkan bahwa istilah khas atau register di Instagram sebagian besar berupa katakata yang termasuk ke dalam kategori derivational words. Oleh karenanya peneliti mengidentifikasi data yang ditemukan kedalam subklasifikasi proses pembentukan kata dalam kategori antara lain: kata dengan afiks, compounding, abbreviation, acronym, blending, dan borrowing/loan words.

\section{Pembentukan Kosakata dengan Unsur Bahasa Inggris}

1. Kata dengan Afiks

Yang dibahas pada bagian ini adalah kata-kata khas di Instagram yang hanya terdiri dari satu kata, namun terbentuk melalui proses afiksasi. Kata-kata khas tersebut antara lain caption, comment, endorse, follower, IGers, repost, reseller, supplier, upload, dan posting. 
Follower adalah sebutan untuk pengikut akun Instagram. Kata 'follower' merupakan kata benda dalam bahasa Inggris terbentuk dari \{'follow'\} $+\{$-er\}. $\{$ Follow $\}$ adalah kata kerja dasar dan sufiks $\{-e r\}$ adalah English derivational suffix. Setelah mengalami proses afiksasi, pembentukan kata baru tersebut berubah menjadi kata benda (noun).

IGers adalah pengguna Instagram. 'IGers' merupakan kata benda dalam bahasa Inggris yang terbentuk dari akronim $\{I G\}+\{$-er $\}$. Sufiks $\{$-er $\}$ merupakan English derivational suffix. Setelah mengalami proses afiksasi, kelas kata dari kata ini tetap menjadi kata benda. Adapun tambahan $\{-s\}$ di akhir kata tersebut merupakan hasil dari English inflectional process. Sufiks $\{-s\}$ tersebut merupakan bentuk pluralisasi kata benda dalam bahasa Inggris.

Posting adalah mengirim sebuah kiriman di akun Instagram. dengan mengirim 'Posting' berasal dari $\{$ post $\}+\{$-ing $\} .\{$ Post $\}$ merupakan kata kerja dasar dan $\{$-ing $\}$ adalah penanda gerund. Penambahan $\{-$ ing $\}$ sebagai penanda gerund ini merubah kelas kata dari kata kerja menjadi kata benda.

Repost adalah posting ulang. 'Repost' merupakan kata kerja bahasa Inggris yang terbentuk dari $\{r e-\}+\{$ post $\}$. Awalan $\{$ re- $\}$ merupakan English derivational prefix dan $\{$ post $\}$ yang merupakan kata kerja adalah kata dasar dari repost. Setelah mengalami proses afiksasi, kelas kata tersebut tetap menjadi kata kerja.

Reseller adalah sebutan untuk penjual tangan kedua. Kata ini terbentuk dari tiga morfem $\{r e-\}+\{$ sell $\}+\{-e r\}$. Kata dasar dari 'reseller' adalah 'sell' (kata kerja). Prefiks $\{r e-\}$ dan sufiks $\{-e r\}$ merupakan English derivational morphemes. Setelah mengalami penambahan dua morfem tersebut, kata kerja 'sell' ini berubah menjadi kata benda.

'Supplier' adalah penyedia barang. Proses morfologis pembentukan kata 'supplier' adalah $\{$ supply $\}+\{-e r\}$. $\{$ Supply $\}$ merupakan kata kerja dan sufiks $\{-e r\}$ merupakan English derivational suffix. Proses afiksasi ini merubah kata dasar yang merupakan kata kerja menjadi kata benda.

Upload adalah mengunggah foto di Instagram. 'Upload' berasal dari $\{u p-\}+$ $\{l o a d\} .\{U p-\}$ merupakan English derivational prefix dan $\{$ load $\}$ adalah bentuk kata kerja dasar. Proses afiksasi ini tidak merubah kelas kata.

Kata-kata yang sudah dibahas di atas merupakan kosakata yang terdiri dari satu kata. Semua kosakata di atas mengalami proses morfologi yaitu penambahan afiks. Penambahan afiks ini dapat berpengaruh terhadap perubahan kelas kata.

\section{Compounding}

Data menunjukkan bahwa kosakata khas instagram yang paling banyak ditemukan berupa kosakata yang terbentuk dari dua kata atau lebih. Jika dilihat dari sumber bahasanya, kosakata khas tersebut terbentuk dari penggabungan kata antara bahasa Inggris + bahasa Inggris, bahasa Indonesia + bahasa Inggris, dan bahasa Inggris + bahasa Indonesia. Dilihat dari proses pembentukan kata, ditemukan beberapa kelompok kata yang terbentuk melalui proses compounding, tetapi dengan jenis yang berbeda-beda, seperti compound noun, compound verb, dan compund adjective. Adapun pembahasannya adalah sebagai berikut:

a. Bahasa Inggris + Bahasa Inggris

Di bawah ini adalah data kosakata yang terbentuk dari 2 kata dengan bahasa sumber yang sama, yaitu bahasa Inggris + bahasa Inggris. Data yang ditemukan 
antara lain activity feed, best seller, double uploads, ghost follower, hit and run, latepost, no cancel, open order, paid promote, real pict, dan spam like.

Activity Feed adalah pemberitahuan mengenai aktivitas yang dilakukan oleh pengguna Instagram terhadap pengguna Instagram lain, seperti memberi like, comment, dan mention. Istilah ini terbentuk dari $\{$ activity $\}+\{$ feed $\}$. Ketika $\{$ activity $\}$ dan $\{$ feed $\}$ berdiri sendiri-sendiri, keduanya adalah kata benda. Namun, setelah keduanya digabungkan, dua kata tersebut membentuk kosakata dan makna baru. \{Activity) menempati kedudukan sebagai modifier (yang menerangkan) dan $\{$ feed $\}$ menjadi head (yang diterangkan). Karena head dari kosakata ini adalah kata benda, maka kosakata ini masuk kedalam kategori compound noun.

Best Seller adalah barang dengan penjualan terbaik. Kosakata ini terbentuk dari gabungan kata $\{$ best $\}+\{$ seller $\}$. $\{$ Best $\}$ adalah adjektif dan $\{$ seller $\}$ adalah noun. Setelah dua kata tersebut digabungkan, maka terbentuk kosakata baru dan memiliki makna baru. \{Best\} menempati kedudukan sebagai modifier dan \{seller\} sebagai head. Karena head dari kosakata ini adalah kata benda, maka kosakata ini masuk kedalam kategori compound noun.

Double upload adalah mengunggah lebih dari satu foto (produk yang dijual). Kosakata ni terbentuk dari gabungan antara $\{$ double $\}+\{$ upload $\}$. Gabungan kata ini membentuk kosakata baru dan makna baru. \{Double $\}$ yang merupakan adjektif menempati kedudukan sebagai modifier dan $\{$ upload $\}$ yang merupakan kata benda menempati kedudukan sebagai head. Kosakata ini juga tergolong sebagai compound noun karena yang menjadi head adalah kata benda.

Ghost Follower adalah follower pasif yang tidak melakukan aktivitas apa pun di akun lain. Kosakata ini terbentuk dari gabungan dua kata benda $\{$ ghost $\}+$ \{follower\}. \{Ghost $\}$ berkedudukan sebagai modifier dan \{follower berkedudukan sebagai head. Kosakata ini masuk kedalam kategori compound noun.

Hit and Run adalah tindakan calon pembeli yang sudah pesan barang dan mendapatkan total harga pesanan, namun hingga jatuh tempo pembayarannya calon pembeli tersebut tidak melakukan transaksi pembayaran. Kosakata ini tersusun dari tiga kata $\{$ hit $\}+\{$ and $\}+\{$ run $\}$. $\{$ Hit $\}$ dan $\{$ run $\}$ merupakan kata kerja dan sama-sama menempati kedudukan head, sedangkan $\{$ and $\}$ adalah kata penghubung. Jika ketiga kata tersebut digabungkan, maka terbentuk kosakata baru dan terbentuk makna baru yang berbeda dari makna kata per kata. Kosakata ini termasuk kedalam jenis coordinative compound karena terdapat dua kata yang berkedudukan sebagai head dalam kosakata ini dan masing-masing head memiliki kedudukan yang setara.

Latepost adalah memposting foto lama di Instagram. Kosakata ini terbentuk dari gabungan $\{$ late $\}+\{$ post $\}$. $\{$ Late $\}$ merupakan adjektif yang berkedudukan sebagai modifier dan $\{$ post $\}$ adalah kata kerja yang berkedudukan sebagai head. Oleh karenanya, kata ini termasuk kedalam kategori compound verb.

No Cancel adalah barang yang sudah dipesan kepada penjual tidak boleh dibatalkan. Kosakata ini terbentuk dari kata $\{$ no $\}+\{$ cancel $\}$. $\{$ No $\}$ merupakan determiner yang menduduki posisi modifier dan \{cancel $\}$ adalah kata kerja yang menduduki posisi head. Jadi, kosakata ini termasuk ke dalam kategori compound verb. 
Open Order adalah saat penjual mulai membuka pesanan permintaan calon pembeli. Kosakata ini tersusun dari kata $\{$ open $\}+\{$ order $\}$. $\{$ Open $\}$ merupakan adjektif yang berkedudukan sebagai modifier, sedangkan \{order adalah kata benda yang berkedudukan sebagai head. Kosakata ini termasuk kedalam kategori compound noun karena head dari kata ini adalah kata benda.

Paid Promote adalah kegiatan promosi berbayar dengan meminta pihak lain, biasanya akun yang sudah banyak followernya, mempromosikan barang dagangannya sesuai dengan waktu yang sudah ditentukan. Kosakata ini terbentuk dari kata $\{$ paid $\}+\{$ promote $\}$. $\{$ Paid $\}$ merupakan bentuk past participle yang berfungsi sebagai adjektif dan berkedudukan sebagai modifier. \{Promote $\}$ adalah kata kerja yang berkedudukan sebagai head. Kosakata ini termasuk kedalam kategori compound verb karena verb menempati head.

Real Pict adaah gambar atau foto asli. Seringkali foto barang yang hendak dijual oleh penjual di Instagram menggunakan foto yang sudah dicopy ataupun sudah diedit. Istilah real pict digunakan untuk memberi informasi bahwa yang diunggah adalah foto asli yang diambil sendiri. Kosakata ini terbentuk dari $\{$ real $\}$ dan $\{$ pict $\}$. $\{$ Real $\}$ adalah adjektif dan $\{$ pict $\}$ merupakan bentuk pemendekan dari kata benda picture. Yang menjadi head dari kosakata ini adalah \{pict $\}$ dan modifiernya adalah $\{$ real $\}$. Kosakata ini termasuk kedalam kategori compound noun.

Spam Like adalah like atas permintaan dengan tujuan agar posting terlihat banyak yang suka. Istilah ini terdiri dari kata $\{$ spam $\}+\{$ like $\}$. $\{$ Spam $\}$ adalah kata benda yang menjadi modifier pada kosakata ini, sedangkan \{like\} juga merupakan kata benda namun berkedudukan sebagai head. Dengan alasan tersebut, kosakata ini termasuk ke dalam kategori compound noun.

b. Bahasa Indonesia + Bahasa Inggris

Di bawah ini adalah data yang terbentuk dari gabungan dari bahasa Indonesia + bahasa Inggris. Yang pertama adalah 'busui friendly' dan yang kedua adalah 'wudhu friendly'.

Istilah 'busui friendly' yang artinya 'ramah untuk ibu menyusui' ini lazim digunakan oleh pengguna Instagram Indonesia pada register jual beli pakaian wanita untuk memberikan sebuah identitas terhadap pakaian yang bisa dengan mudah dikenakan dan difungsikan oleh ibu menyusui. Biasanya pakaian yang dimaksud ini memiliki resleting di bagian dada.

Jika dilihat dari struktur pembentuk kosakata, kata ini terbentuk dari gabungan kata $\{$ busui $\}+\{$ friendly $\}$. Kata $\{$ busui $\}$ sendiri merupakan kata benda bahasa Indonesia yang terbentuk melalui proses blending pengambilan suku kata akhir dari kata $\{\mathrm{ibu}\}+\{$ menyusui $\}$ '. \{Friendly $\}$ adalah sebuah kata sifat atau adjektif bahasa Inggris yang artinya ramah.

Jika dilihat dari kaidah sistem bahasanya, maka istilah ini menganut sistem bahasa Inggris yang terbentuk dari proses compounding. Hal ini dapat dibuktikan dengan cara menganalisis susunan modifier dan head dari kata tersebut. \{Friendly\} yang merupakan kata sifat menempati posisi head. Sedangkan \{busui\} menjadi modifier atau penjelas dari $\{$ friendly $\}$. Dalam sistem bahasa Inggris, struktur gabungan kata umumnya adalah modifier + head (MH). Sebaliknya, dalam bahasa Indonesia struktur gabungan kata diawali oleh head dan baru diikuti 
oleh modifier. Jadi, gabungan kata pada contoh ini tergolong kedalam compound adjective.

Selain 'busui friendly', ditemukan istilah yang hampir serupa, yaitu 'wudhu friendly', yang artinya 'mudah digunakan untuk wudhu'. Kata ini juga lazim digunakan oleh pengguna Instagram Indonesia pada register jual beli pakaian wanita, khususnya wanita muslimah. Istilah 'wudhu friendly' digunakan untuk memberikan identitas pada pakaian muslimah yang mudah difungsikan saat berwudhu. Biasanya bagian pergelangan tangan dari pakaian ini terdapat kancing, resleting, atau karet sehingga memudahkan pemakainya saat hendak berwudhu.

Sama halnya dengan 'busui friendly', 'wudhu friendly' juga tersusun dari bahasa Indonesia dan bahasa Inggris. Kata ini tersusun dari kata benda dan adjektif $\{$ wudhu $\}+\{$ friendly $\}$. \{wudhu $\}$ adalah kata benda yang merupakan kosakata bahasa Arab yang sudah menjadi kata serapan dalam bahasa Indonesia. Seperti yang sudah dijelaskan sebelumnya, \{friendly\} adalah adjektif bahasa Inggris. Adapun kaidah susunan kata tersebut juga mengikuti sistem bahasa Inggris. Proses pembentukan kata ini juga tergolong ke dalam compound adjective.

c. Bahasa Inggris + Bahasa Indonesia

Ada beberapa istilah unik yang digunakan oleh pengguna Instagram yang tersusun dari gabungan bahasa Inggris dan bahasa Indonesia. Di antaranya adalah 'free ongkir', 'no gembok', dan 'paid keroyok'.

Istilah 'free ongkir' ini umum digunakan dalam kegiatan jual beli online oleh pengguna Instagram di Indonesia. Arti dari istilah tersebut adalah 'bebas ongkos kirim'. Istilah ini merujuk pada pengiriman barang yang dibeli secara online yang bebas dari biaya pengiriman. Kata ini terbentuk dari gabungan adjektif bahasa Inggris \{free\} yang berarti 'bebas' dan kata benda bahasa Indonesia \{ongkir\} yang merupakan kata yang telah melalui proses blending dari pengambilan suku kata pertama dari kata \{ongkos $\}+\{$ kirim $\}$. Struktur pembentukan kata 'free ongkir' ini dapat ditemukan pada sistem morfologi bahasa Inggris. Kata ini tersusun dari adjektif dari bahasa Inggris $\{$ free $\}$ dan kata benda dari bahasa Indonesia \{ongkir\}. Kata ini termasuk kedalam kelompok compund noun karena head dari gabungan dua kata ini berupa noun atau kata benda. Contoh kosakata bahasa Inggris lain yang didahului oleh kata 'free' dan mempunyai struktur yang sama dengan kata di atas adalah 'free market', 'free verse', 'free spirit', dsb. Namun, dalam bahasa Indonesia, ditemukan juga struktur kosakata yang mirip dengan kosakata yang dibahas di atas, yaitu 'bebas biaya', 'bebas denda', dan 'bebas banjir'.

Datum berikutnya yang berhasil ditemukan adalah istilah 'no gembok'. Arti dari kata ini adalah 'tidak digembok'. Istilah ini biasa digunakan oleh sebagian toko online di Instagram untuk memberi informasi kepada pengguna Instagram lain bahwa akun miliknya boleh dilihat secara bebas. Istilah 'gembok' digunakan karena simbol 'gembok' muncul pada akun Instagram yang di-setting privat. Apabila pengguna Instagram menemukan gambar 'gembok' tersebut, maka dia tidak dapat mendapat akses untuk melihat foto dan kiriman lain dari akun tersebut.

Istilah 'no gembok' ini terbentuk dari gabungan kata bahasa Inggris dan bahasa Indonesia $\{$ no $\}+\{$ gembok $\}$. Jika dilihat dari strukturnya, kata ini seperti 
mengikuti kaidah pembentukan kata bahasa Inggris. Susunannya mengikuti pola MH (modifier head). \{ No $\}$ merupakan adverbia yang menduduki posisi modifier dan \{gembok\} merupakan kata benda yang menduduki posisi head. Jika mengikuti kaidah bahasa Indonesia, maka kata benda 'gembok' pasti akan menjadi bentuk pasif 'digembok'. Kata ini termasuk kedalam kategori compound noun karena head dari kata tersebut adalah kata benda.

Datum yang lainnya yang berhasil penulis peroleh adalah istilah 'paid keroyok'. 'Paid keroyok' adalah sebuah istilah yang familiar bagi para pebisnis online di Instagram. Pengertian dari istilah ini adalah sebuah bentuk promosi berbayar yang dilakukan oleh sebuah toko online dengan cara 'menitipkan' foto dagangannya di puluhan toko online lainnya di Instagram.

Istilah yang cukup unik ini terbentuk dari paduan kata dari bahasa Inggris dan bahasa Indonesia \{paid $+\{$ keroyok $\}$. \{Paid $\}$ merupakan bentuk past participle yang berfungsi sebagai adjektif. Kedudukan kata ini sebagai modifier. Sedangkan \{keroyok\} adalah kata kerja yang menempati posisi head. Karena yang menjadi head adalah kata kerja, maka paduan kata ini dikategorikan sebagai compound verb. Adapun kaidah pembentukan kata pada kosakata ini mengikuti sistem bahasa Inggris.

Dari hasil analisis yang dilakukan, tiga kosakata khas Instagram yang terbentuk dari paduan bahasa Inggris dan bahasa Indonesia mengalami proses compounding. Pola pembentukan kosakata pada tiga kosakata tersebut semuanya mengikuti kaidah pembentukan kata yang terdapat dalam sistem bahasa Inggris.

\section{Abbreviation}

Abbreviation adalah bentuk pemendekan kata yang sudah ada menjadi sebuah kata yang baru. Penulis menemukan pembentukan kosakata yang melalui proses ini di media sosial Instagram, namun tidak banyak. Kosakata tersebut adalah 'bio', 'del' dan 'pict'. 'Bio' adalah pemendekan dari kata biography. 'Del' adalah pemendekan dari kata 'delete'. 'Pict' adalah kependekan dari kata picture. Semua data berasal bahasa Inggris.

\section{Acronym}

Akronim adalah pemendekan kata dengan cara mengambil satu huruf pertama pada masing-masing kata yang akan disingkat. Ada beberapa akronim yang ditemukan di Instagram, diantaranya yaitu $D M, I G, K / D, L F L, O O T D, P O$, dan $S F S$. Semua data yang berupa akronim ini terbentuk dari bahasa Inggris. Masing-masing singkatan tersebut dibahas di bawah ini.

DM merupakan akronim dari 'direct message'. DM ini adalah pesan langsung, semacam SMS, yang diberikan oleh seseorang melalui fitur khusus yang terdapat di menu Instagram.

IG merupakan akronim dari Instagram.

IDR merupakan akronim dari Indonesia Rupiah. Pebisnis online di Instagram sering menggunakan istilah IDR untuk menyatakan rupiah.

$K$ adalah singkatan dari kosakata bahasa Inggris 'kilo' yang artinya 'ribu'. Singkatan ini banyak ditemukan di Instagram. Biasanya digunakan setelah angka atau nominal tertentu. Contoh: 100K, maka artinya seratus ribu. 
K/D adalah singkatan dari 'Keep or Delete'. Istilah ini digunakan oleh seorang pengguna Instagram untuk menanyakan kepada pengikutnya apakah kiriman foto atau kiriman lainnya di Instagran yang dia perlu dihapus atau dipertahankan.

LFL yaitu singkatan dari 'Like For Like'. LFL merupakan aktivitas saling memberi 'like'. Saat seorang pengguna Instagram memberikan 'like' terhdap posting pengguna lain, maka yang diberi 'like' juga diminta memberikan 'like' terhadap postingannya.

OOTD adalah singkatan dari 'Outfit of The Day'. Akronim ini mengacu pada pakaian dan asesoris yang dikenakan oleh seseorang di sebuah posting foto. Tujuannya adalah untuk 'memamerkan' fesyen yang ia kenakan pada hari itu melalui posting foto di Instagram.

$P O$ merupakan singkatan dari 'Pre Order'. Istilah ini digunakan untuk memberi informasi bahwa barang dagangan belum tersedia dan harus dipesan terlebih dahulu.

SFS adalah singkatan dari 'Shoutout For Shoutout'. SFS merupakan sebuah kegiatan promosi di Instagram dengan cara saling mempromosikan barang dagangan antara penjual satu dengan yang lainnya.

\section{Blending}

Blending merupakan proses pembentukan kata baru dari kosakata yang sudah ada sebelumnya dengan menyingkat sebagian suku kata. Ada beberapa istilah di Instagram dengan unsur bahasa Inggris yang terbentuk dari proses blending, diantaranya yaitu delsoon, focap, follback, geotag, olshop, dan selfie. Terdapat kosakata lain khas Instagram yang terbentuk dari proses blending, seperti 'selebgram'; namun kosakata tersebut terbentuk hanya dari unsur bahasa Indonesia. Kosakata yang akan dibahas di sini hanyalah kosakata yang mengandung unsur bahasa Inggris.

Delsoon adalah pemendekan dari kata 'delete soon'. Istilah ini digunakan untuk memberi informasi bahwa sesaat setelah foto diposting, foto tersebut akan segera dihapus. Dua kata pembentuk kosakata ini adalah kosakata bahasa Inggris. Bagian kata yang di-blending adalah suku kata pertama pada kata pertama \{delete\} kemudian digabungkan dengan kata yang kedua $\{$ soon $\}$. Kata $\{$ soon $\}$ hanya terdiri dari satu suku kata sehingga kata ini tidak dapat dipendekkan.

Focap adalah pemendekan dari kata 'foto caption'. Maksud dari istilah ini ialah penjelasan atau deskripsi singkat pada foto yang di-posting di Instagram. Dua kata pembentuk kosakata berasal dari dua bahasa yang berbeda. Kata 'foto' adalah kosakata bahasa Indonesia yang merupakan kata serapan dari kosakata bahasa Inggris 'photo'. Sedangkan 'caption' adalah kosakata bahasa Inggris. Bagian kata yang diblending adalah suku kata pertama pada kata pertama \{foto $\}$ dan suku kata pertama pada kata kedua $\{$ caption $\}$.

Follback adalah bentuk konfirmasi seorang pengguna Instagram setelah mendapat persetujuan menjadi pengikut (follower) pengguna lain dan memintanya untuk menjadi followernya. Follback terbentuk dari dua kosakata bahasa Inggris 'follow' dan 'back'. Proses blending kata ini adalah dengan mengambil suku kata pertama dari kata pertama \{follow $\}$ dan langsung menggabungkannya dengan kata kedua $\{$ back $\}$ tanpa memendekkannya. Kata kedua tidak dipendekkan karena hanya terdiri dari satu suku kata. 
Geotag adalah lokasi yang dimunculkan pada sebuah postingan. Fungsinya adalah menunjukkan lokasi pada saat seseorang membuat postingan di Instagram. Istilah ini berasal dari dua kosakata bahasa Inggris 'geography' dan 'tag'. Proses blending kata ini adalah dengan mengambil suku kata pertama pada kata pertama \{geography\} dan menggabungkannya langsung dengan kata kedua $\{$ tag $\}$. Kata kedua tidak dipendekkan karena hanya memiliki satu suku kata.

Istilah 'olshop' mulai familiar di telinga masyarakat Indonesia sejak munculnya kegiatan perniagaan di dunia maya. 'Olshop' berasal dari dua kosakata bahasa Inggris 'online' dan 'shop'. Kata ini merupakan hasil blending dari pengambilan huruf pertama pada suku kata pertama dan huruf pertama pada suku kata kedua pada kata pertama\{online\} lalu digabungkan lansung dengan kata kedua $\{$ shop $\}$. Kata kedua tidak dipendekkan karena hanya terdiri dari satu suku kata.

\section{Borrowing}

Borrowing merupakan bentuk pemakaian kosakata yang dipinjam dari bahasa lain. Selain kosakata yang sudah dibahas sebelumnya, di Instagram Indonesia banyak ditemukan penggunaan kosakata asing, khususnya bahasa Inggris, oleh para penggunanya. Istilah-istilah atau kosakata bahasa Inggris tersebut lebih umum digunakan daripada padanannya dalam bahasa Indonesia. Kosakata tersebut antara lain online (daring), upload (mengunggah), comment (komentar), customer (pembeli), endorse (merekomendasikan), caption (keterangan), follower(s) (pengikut), done (selesai) keep (simpan), like (suka), giveaway (hadiah), spam (sampah), seller (penjual), post/posting (kirim), dan istilah lainnya yang mengandung unsur bahasa Inggris seperti pada pembahasan-pembahasan sebelumnya.

Sebagian besar kosakata yang dibahas diatas hanya dipahami oleh orang-orang yang sering berinteraksi di Instagram. Hal ini pernah dialami sendiri oleh peneliti. Saat pertama kali berinteraksi di media sosial tersebut, banyak istilah-istilah khas yang tidak dimengerti oleh peneliti karena kata-kata tersebut tidak digunakan oleh pengguna bahasa di luar Instagram. Dengan berjalannya waktu dan lebih seringnya peneliti dalam interaksi di instagram, peneliti akhirnya dapat memahami arti kosakata tersebut. Peneliti juga melakukan triangulasi terhadap orang-orang di sekitar yang tidak atau belum pernah berinteraksi di Instagram. Peneliti melontarkan kosakata tersebut dan menanyakan artinya. Mereka pun tidak memahami arti dari sebagian besar kosakata tersebut, kecuali beberapa kata yang pernah mereka dengar dari percakapan sehari-hari. Sehingga jelas bahwa kosakata yang penulis temukan diatas dapat dikategorikan sebagai register atau jargon bidang perniagaan di media sosial instagram. Hal ini sesuai dengan pendapat Radford (2009: 226), "A register is the specialized vocabulary common to particular trade, occupation, topic or activity." Register adalah kosakata khas yang biasa digunakan dalam bidang perniagaan, pekerjaan, atau aktivitas tertentu. Radford (2009: 226) juga menambahkan "The term "jargon" is sometimes used to refer to the confusing registers of particular activity." Jargon adalah register khas untuk suatu kegiatan tertentu. Dalam Kamus Linguistik, jargon didefinisikan sebagai kosakata yang khas yang dipakai dalam bidang kehidupan tertentu, seperti yang dipakai oleh montir-montir mobil, tukang kayu, guru bahasa, dan sebagainya yang tidak dipakai dan tidak dipahami oleh orang dari bidang lain (Kridalaksana, 2001: 98). Jadi, dapat dikatakan bahwa data kosakata yang ditemukan di atas adalah register bidang perniagaan khas online shop di instagram. 
Kemudian muncul sebuah asumsi alasan para IGers (para pengguna Instagram) ini menggunakan register khas Instagram tersebut. Beberapa alasan atau kemungkinan yang dapat melatarbelakangi penutur dalam suatu kelompok tertentu menggunakan register atau jargon. "Some registers, however, are deliberately confusing so as to hinder understanding by outsiders. This may be because the group speaking the particular register wants to maintain a sharply contrasting identity, or has something to hide (Radford, 2009: 226). Alasan pertama yaitu suatu kelompok menggunakan register untuk menunjukkan identitasnya; dan yang kedua mereka menggunakan register karena ingin menyembunyikan sesuatu dari kelompok lain atau orang lain. Alasan pertama bisa lebih berterima dibanding dengan alasan yang kedua. Penggunaan register khusus di media ini tidak bertujuan untuk menyembunyikan sesuatu karena media sosial Instangram adalah tempat komunikasi publik. Siapa pun dapat melihat foto yang diunggah, membaca caption, membaca dan memberi komentar, atau kiriman yang lain. Oleh karenanya, pada kasus istilah-istilah khas yang ditemukan di Instagram Indonesia, para pengguna cenderung menjadikan istilah-istilah tersebut sebagai identitas. Mereka menggunakan register khusus untuk menunjukkan bahwa mereka merupakan bagian dari kelompok tersebut.

Bahasa memiliki sifat yang dinamis. Penggunaan istilah dari bahasa Inggris menjadi suatu hal yang tidak dapat dihindarkan dalam komunikasi media sosial. Begitupun penggunaan istilah khas atau jargon tidak dapat dihindari, bahkan justru dapat menjadi sebuah ciri atau identitas tertentu dari pengguna suatu media sosial.

Dari temuan dan pembahasan di atas, penulis dapat menemukan implikasi kebahasaan yaitu terbentuknya istilah-istilah khas di Instagram dengan unsur bahasa Inggris dapat menambah kekayaan perbendaharaan kata dalam bahasa Indonesia. Di sisi lain, penggunaan istilah bahasa asing, dalam hal ini bahasa Inggris, dalam pembentukan kosakata baru yang tidak mengikuti kaidah kebahasaan yang berlaku dapat menimbulkan adanya interferensi atau kekacauan bahasa. Kekacauan bahasa tersebut dapat berupa kekacauan sistem morfologi, baik bahasa Inggris maupun bahasa Indonesia, dan juga sistem ejaan. Bentuk-bentuk kekacauan bahasa ini perlu kajian lebih lanjut.

\section{SIMPULAN}

Dari penelitian yang sudah dilakukan, peneliti menarik simpulan bahwa terdabat sejumlah kata khas Instagram yang di dalamnya memuat unsur bahasa Inggris. Kata-kata tersebut terbentuk dari kombinasi bahasa antara lain bahasa Inggris + bahasa Inggris, bahasa Inggris + bahasa Indonesia, dan bahasa Indonesia + bahasa Inggris. Dilihat dari proses pembentukan kata, istilah-istilah tersebut terbentuk melalui berbagai macam proses morfologis, antara lain proses derivating, compounding, abbreviating, blending, acronym, dan borrowing. Yang paling banyak ditemukan adalah proses compounding. Temuan yang lainnya adalah sistem bahasa yang digunakan dalam pembentukan istilahistilah khas tersebut juga berbeda-beda. Terdapat kosakata yang mengikuti kaidah pembentukan kata seperti dalam sistem bahasa Inggris. Sebaliknya, terdapat kosakata yang mengikuti sistem bahasa Indonesia. Terdapat pula kosakata yang mengikuti gabungan dari dua sistem bahasa tersebut. Terbentuknya kosakata baru melalui proses yang bermacam-macam ini merupakan proses kreatif manuasia yang dapat memberikan dampak positif terhadap perbendaharaan kosakata baru terhadap suatu bahasa. Namun, pembentukan kosakata baru yang tidak mengikuti kaidah bahasa yang benar dapat mengacaukan sistem bahasa yang sudah ada. 
Komunikasi di media sosial menjadi topik yang menarik untuk dikaji. Penelitian ini merupakan preliminary study atau kajian awal mengenai pembentukan kosakata khas di Instagram yang masih memerlukan kajian lanjutan. Kosakata khas yang ditemukan dan dibahas dalam penelitian ini masih terbatas pada register tertentu. Kedepannya, penelitian ini dapat dikembangkan dengan membahas kosakata khas yang lebih banyak lagi dan juga mencakup pada register lain. Saran bagi masyarakat, sebaiknya pengguna Instagram bisa lebih bijak menggunakan kata-kata yang tidak mengacaukan sistem bahasa.

\section{DAFTAR PUSTAKA}

Anonym. (2016). Mau eksis? Pahami dulu 30 istilah dan singkatan dalam instagram beserta artinya. Retrieved December 20, 2016, from http://tekoneko.net/istilahdalam-instagram/

Chaer, A. (2008). Morfologi bahasa Indonesia (pendekatan proses). Jakarta: PT. Rineka Cipta.

Chaer, A., \& Agustina, L. (2004). Sosiolinguistik: Perkenalan awal. Penerbit PT Rineka Cipta.

Delahunty, G. P. \& Garvey, J. J. (2010). The English Language: From sound to sense perspectives on writing. Retrieved from http://wac.colostate.edu/books/sound/

Kridalaksana, H. (2001). Kamus linguistik. Jakarta: PT Gramedia Pustaka Utama.

Maghribi, A. M. (2016). Arti istilah di instagram. Retrieved January 2, 2017, from http://lenterahidup.net/arti-istilah-di-instagram

Mahsun. (2007). Metode penelitian bahasa: Tahapan strategi, metode, dan tekniknya (Revisi). Jakarta: Rajawali Pers.

Mustikawati, D. A. (2006). Interferensi bahasa Indonesia ke dalam pemakaian bahasa Inggris wacana tulis Siswa SMA Muhammadiyah 1 Ponorogo. Program Pascasarjana Universitas Sebelas Maret.

Radford, A., Atkinson, M., Britain, D., Clahsen, H., \& Spencer, A. (2009). Linguistics: an introduction. Cambridge University Press.

Romeltea. (2014). Media sosial: Pengertian, karakteristik, dan jenis. Retrieved from https://www.romelteamedia.com/2014/04/media-sosial-pengertiankarakteristik.html

Saragih, F. A. (2013). Interferensi bahasa Indonesia terhadap penggunaan adposisi bahasa Jepang pada bahasa tulis (studi kasus terhadap mahasiswa angkatan 2010 Sastra Jepang Universitas Brawijaya Malang). Paramasastra, 1(1), 22-42. Retrieved from https://journal.unesa.ac.id/index.php/paramasastra/article/view/1468/983 
Sudaryanto. (1993). Metode dan aneka teknik analisis bahasa: Pengantar penelitian wahana kebudayaan secara linguistik. Yogyakarta: Duta Wacana University Press. 